\title{
Smartphone Usage and Pattern on Self-reported Symptoms Among Medical Students in Universiti Kebangsaan Malaysia During the COVID-19 Lockdown
}

Puteri Sofia Nadira Megat Kamaruddin

Universiti Kebangsaan Malaysia https://orcid.org/0000-0002-1499-8583

Azmawati Mohammed Nawi ( $\square$ azmawati@ppukm.ukm.edu.my )

Universiti Kebangsaan Malaysia https://orcid.org/0000-0002-0009-5244

Research

Keywords: medical student(s), pattern, symptoms, smartphone, usage, COVID-19

Posted Date: September 1st, 2020

DOl: https://doi.org/10.21203/rs.3.rs-67820/v1

License: (c) (1) This work is licensed under a Creative Commons Attribution 4.0 International License. Read Full License 


\section{Abstract \\ Background}

Smartphone ubiquitous has become profound especially during 2019 Coronavirus Disease (COVID-19) lockdown period. It is worth considering the influence on users' health symptoms, which extend beyond the realm of communication. Prior research suggests smartphone's usage and pattern correlated with self-reported symptoms from different countries. Hence, this research aimed to evaluate the smartphone usage and pattern, also its association on self-reported symptoms among medical students in Malaysia, which occurred during COVID-19 lockdown implementation.

\section{Methods}

A cross-sectional study was conducted, with 252 medical students enrolled in the study at Universiti Kebangsaan Malaysia (UKM) using proportionate stratified random sampling. Sociodemographic, socioeconomic characteristics, smartphone usage and pattern also self-reported symptoms were derived from the self-administered questionnaire. Student's t-test, Pearson's Chi Square and Pearson's correlation were used to determine the association of factors (sociodemographic, socioeconomic status and academic performance) on smartphone usage and pattern. Simple and Multiple Linear Regression (MLR) were performed to seek the main factor contributing to the association of smartphone usage and pattern on self-reported symptoms.

\section{Results}

Smartphone usage SAS-M score was 101.43 (25.15). Smartphone pattern revealed an average of 7 years owning a smartphone, make or receive calls about 32 minutes per day and spend around 4 hours per day other than calls, and the participants equally use their smartphone for entertainment (50\%) and nonentertainment (50\%) purposes. They have about one extra device besides their smartphone and usually would first use their smartphone within 15 minutes after wake-up in the morning. Employed father status (Adj. $\beta=7.431,95 \%$ Cl: 3.069, 11.793) and entertainment (Adj. $B=4.211,95 \% \mathrm{Cl}$ : 0.460, 7.962) as most personally relevant smartphone function are the significant main predictors for self-reported symptoms after controlling other factors.

\section{Conclusions}

These results suggest that father's occupation and entertainment function of smartphone pattern affect self-reported symptoms among medical students in the setting of ongoing COVID-19 pandemic. Parents' active participation is crucial from early childhood education on proper ways to utilise smartphones, also having support system on seeking various ways of entertainment. Public campaigns promoting 
awareness on proper way of utilising smartphone to avoid the tendency of smartphone addiction are essential.

\section{Background}

More people have been using smartphones in the last decade, especially the young adults who own their first smartphones at a younger age. One study revealed the average age at which Spanish teens were 13 years old when they got their first smartphone in 2005, while Korean children and adolescents own at 10 years old in $2011(1,2)$. They use mobile phones not only to keep in touch with their relatives or friends, but also as a source of entertainment, such as playing games and surfing the internet, revealing that smartphone use has absorbed the early stages of their life (3).

They are widely believed to be more vulnerable to symptoms from the use of smartphones as they are more susceptible. It is reportedly the result of a deeper penetration of microwave radiation into children's brains. In addition, it has been reported that smartphone usage can alter the permeability of the bloodbrain barrier (4). Considering the popularity of smartphone usage among students, they are usually among the frequent users of this common electromagnetic field (EMF) source and they tend to use smartphones beyond extended periods of time while at home (4).

Given the potential health effects of smartphones on human development, research that explored the associations between smartphone use and well-being among young people has gradually increased (58). As for the safety of smartphones, they are a fairly new technology. Therefore, scientists do not yet have a long-term tracking of their possible health effects (9). Since the physiological functions of the human body are regulated by electrical currents, we may assume that placing the human body in a sufficiently strong electromagnetic field will affect physiological processes (10). Although the vast majority of recent research projects focus on cancer, electromagnetic fields (EMFs) are also suspected as a potential cause of such diseases like sleep disorders, headaches or allergy-like symptoms (4). Even the majority of private university students in Malaysia confirmed that smartphones that cause headache, memory loss and sleep disorders (11). A local study carried out among university students in 2009 found that those who spent more time with smartphones were more vulnerable to psychological disorders induced by unhealthy and unregulated use of smartphones (12). Most of the research focussed on psychological illness as a smartphone influence in Malaysia $(8,12-15)$.

On 18th March 2020, effective nationwide, the Government of Malaysia has adopted extraordinary steps to restrict viral transmission and reduce contact with people infected with COVID-19 and to curb the outbreak (16). The population of Malaysia has been subjected to a considerable period of social isolation, with restrictions on movements for all sectors except the essential ones (17). Measures of social distancing were also imposed. Many people were detained at home, enabling them to go out to work only if their physical presence was considered important and they are only permitted to leave home if it is strictly required. 
Based on the research evidence of smartphone effect and its association with the severity of symptoms experienced, we speculate the possibilities during COVID-19 social distancing, as smartphone will be utilised for various purposes such as, learning, human connection and even distraction with entertainment. The goal of this study was therefore to determine the usage and pattern of smartphones, as well as their association with self-reported symptoms among UKM medical students, since they are equipped with medical knowledge to distinguish the symptoms experienced. We hypothesized that the higher smartphone usage and pattern duration, the higher number of self-reported symptoms experienced.

\section{Methods}

This was a cross-sectional study using proportionate stratified random sampling conducted among the local undergraduate medical students of UKM who are smartphone owners, in March till April 2020 (16). This period was also the time of nationwide quarantine due to the COVID-19 global pandemic (16). The medical students were assigned into stratums categorised as: Pre-clinical (first and second years) and Clinical (third, fourth and fifth years). Then, randomisation of the participants' matric numbers was performed within each stratum using random number generator at the following link, https://www.random.org/. Those who were being diagnosed or under treatment for diseases like psychiatric illness or malignancy, having medical history of thyroid disease, anaemia, explicit use of drug, pregnant or currently hospitalised for any health events were excluded from the study. Participation was voluntary with assurance that their information remained private, since there were no identifiers or personal details collected.

The sample size for this study is 252 participants, which has included $10 \%$ for incomplete data or dropout rate based on Kish formula (18) from the literature by Abed et al (19); derived from the self-reported physical symptoms value of, "Pain in the neck muscle, $58.52 \%, n=134$ ". In this study, sample size calculation was derived by setting the power to $80 \%$ and Type I Error to 0.05 . Where precision was used, $95 \% \mathrm{Cl}$ (confidence interval) and precision of $5 \%$ was set.

\section{Study tools}

In this study a self-administered English language questionnaire was used. Researcher approached the potential participants from the generated random list of medical students. Then, the participants were given the questionnaire and their responses were recorded on the web-based Google sheet form. The questionnaire took approximately 15 minutes to be completed and consists of 4 sections.

The first section is information about sociodemographic and socioeconomic characteristics; information on age, gender, race, parents' income, occupation and education levels, also student's scholarship status and academic performance. The second section is about smartphone pattern; frequency of the smartphone use on a typical day, duration of owning a smartphone, time until morning smartphone first uses, number of additional devices possessed and most relevant smartphone function. 
The third section requires information about smartphone usage; using English version of Smartphone Addiction Scale - Malay (SAS-M) (20), the original scale of versions produced by Kwon et al (21) was adapted, translated and validated among medical students in Malaysia with Cronbach alpha 0.94 (20). SAS-M Includes 33 items and has six subscales (cyber-space-oriented relationship, daily life disturbance, primacy, overuse, positive anticipation and withdrawal). Pilot study was conducted, which the Cronbach alpha among 30 volunteers was 0.91 , and the coefficients respectively for the six factors were $0.78,0.76$, $0.86,0.67,0.83$ and 0.85 . Each question is given a response scale of 1 to $6(1=$ strongly disagree to $6=$ strongly agree), whereby, the score range is $33-198$, with higher scores showing higher risk of smartphone addiction or use (20).

While the fourth section is regarding self-reported symptoms; rated on 10 symptoms that they perceived they experienced when using smartphones and Total Score of Severity (TSS) are calculated for each student (22). All self-reported symptoms were rated on a scale of 0 to 10 whereby, scale 0 represents as none and scale 10 represents frequently daily. The score range is $0-100$, which higher scores indicating the severity of self-reported symptoms experienced. TSS is the sum of the self-reported symptoms $\times$ severity of each symptom using the equation below (22):

TSS for each individual $=\Sigma$ (Self-reported symptom $\times$ Severity factor of that symptom)

\section{Data Analysis}

All data were entered and analysed using the Statistical Package for Social Sciences software version 25. The descriptive statistical analysis of data was carried out to determine the means and standard deviations (SD) for continuous variable, while frequencies and percentages (\%) for categorical variables. Student's t-test, Pearson's Chi Square and Pearson's correlation were used to determine the association of factors (sociodemographic, socioeconomic status and academic performance) on smartphone usage and pattern. Simple and Multiple Linear Regression (MLR) were performed to determine the main factor contributing to the association of smartphone usage and pattern on self-reported symptoms. All tests conducted were two-sided and considered significant if $p<0.05$.

\section{Results}

The participants' characteristics as well as smartphone usage and pattern presented in Table 1 revealed the average age was around 23.09 (1.84) years old, by which $75.4 \%$ were females, $59.9 \%$ were of Malay descendants, with the remainder were mostly Chinese (18.7\%) and Indians (16.7\%). The participants' parents grossly earned RM6641.57 (7067.56) monthly through which, $40.1 \%$ of fathers completed tertiary education while $38.5 \%$ of mothers completed secondary education. The majority of both parents were employed comprising 75.4 percent of fathers and 54 percent of mothers. Approximately $80.6 \%$ of the participants were not receiving any scholarship or loan to support their current medical studies and their last semester academic performance in all the subjects were CGPA $3.2(0.37)$. 
Table 1

Participant's characteristics also smartphone usage and pattern

\begin{tabular}{|c|c|c|}
\hline \multirow[t]{2}{*}{ Participant's Characteristics } & $\mathrm{n}(\%)$ & Mean (SD) \\
\hline & \multicolumn{2}{|l|}{$N=252$} \\
\hline Socio-demography & & $23.09(1.84)$ \\
\hline \multicolumn{3}{|l|}{ Age (years) } \\
\hline $\begin{array}{l}\text { Gender } \\
\text { Male }\end{array}$ & \multicolumn{2}{|l|}{$\begin{array}{l}62 \\
(24.6)\end{array}$} \\
\hline Male & \multirow{2}{*}{\multicolumn{2}{|c|}{$\begin{array}{l}190 \\
(75.4)\end{array}$}} \\
\hline Female & & \\
\hline \multicolumn{3}{|l|}{$\begin{array}{l}\text { Race } \\
\text { Malay }\end{array}$} \\
\hline Malay & \multirow{2}{*}{\multicolumn{2}{|c|}{$\begin{array}{l}47 \\
(18.7)\end{array}$}} \\
\hline Chinese & & \\
\hline Indian & \multicolumn{2}{|l|}{$\begin{array}{l}42 \\
(16.7)\end{array}$} \\
\hline \multirow[t]{2}{*}{ *Others } & \multirow{2}{*}{\multicolumn{2}{|c|}{$12(4.8)$}} \\
\hline & & \\
\hline \multicolumn{2}{|l|}{ Socio-economy } & 6641.57 \\
\hline \multicolumn{3}{|l|}{ Parents' income (RM) } \\
\hline Parents' occupation & \multirow{2}{*}{\multicolumn{2}{|c|}{$\begin{array}{l}190 \\
(75.4)\end{array}$}} \\
\hline Father & & \\
\hline Employed & \multicolumn{2}{|l|}{$\begin{array}{l}62 \\
(24.6)\end{array}$} \\
\hline Unemployed & \multirow{2}{*}{\multicolumn{2}{|c|}{$\begin{array}{l}136 \\
(54.0)\end{array}$}} \\
\hline Mother & & \\
\hline Employed & \multicolumn{2}{|l|}{$\begin{array}{l}116 \\
(46.0)\end{array}$} \\
\hline Unemployed & & \\
\hline
\end{tabular}

Abbreviations: $S D$ standard deviation, RM Ringgit Malaysia

*Others, $\mathrm{n}(\%)$ : Bumiputera 3 (1.2), Kadazan 2 (0.8), Bajau 1 (0.4), Bidayuh 1 (0.4), Bugis 1 (0.4),

Dusun 1 (0.4), Punjabi 1 (0.4), Siamese 1 (0.4), Sino-Kadazan 1 (0.4) 


\begin{tabular}{|c|c|c|}
\hline Participant's Characteristics & $\begin{array}{l}n(\%) \\
N=252\end{array}$ & Mean (SD) \\
\hline Parents' education level & $2(0.8)$ & \\
\hline Father & $18(7.1)$ & \\
\hline Nil & $\begin{array}{l}77 \\
(30.6)\end{array}$ & \\
\hline Secondary & $\begin{array}{l}54 \\
(21.4)\end{array}$ & \\
\hline Diploma / Certificate & $\begin{array}{l}101 \\
(40.1)\end{array}$ & \\
\hline Tertiary & $4(1.6)$ & \\
\hline Mother & $15(6.0)$ & \\
\hline Primary & $\begin{array}{l}97 \\
(38.5)\end{array}$ & \\
\hline Secondary & $\begin{array}{l}53 \\
(21.0)\end{array}$ & \\
\hline Tertiary & $\begin{array}{l}83 \\
(32.9)\end{array}$ & \\
\hline $\begin{array}{l}\text { Scholarship status } \\
\text { Yes } \\
\text { No }\end{array}$ & $\begin{array}{l}49 \\
(19.4) \\
203 \\
(80.6)\end{array}$ & \\
\hline Academic performance (CGPA) & & $3.2(0.37)$ \\
\hline $\begin{array}{l}\text { Smartphone usage and pattern } \\
\text { Smartphone usage } \\
\text { SAS-M score }\end{array}$ & & $101.43(25.15)$ \\
\hline $\begin{array}{l}\text { Smartphone pattern } \\
\text { Duration of smartphone use making or receiving calls on a typical day } \\
\text { (minutes) }\end{array}$ & & $32.17(49.97)$ \\
\hline Duration of smartphone use other than calls on a typical day (hours) & & $4.26(4.29)$ \\
\hline Duration of owning a smartphone (years) & & $7.23(2.77)$ \\
\hline
\end{tabular}

Abbreviations: $S D$ standard deviation, RM Ringgit Malaysia

*Others, $\mathrm{n}(\%)$ : Bumiputera 3 (1.2), Kadazan 2 (0.8), Bajau 1 (0.4), Bidayuh 1 (0.4), Bugis 1 (0.4), Dusun 1 (0.4), Punjabi 1 (0.4), Siamese 1 (0.4), Sino-Kadazan 1 (0.4) 


\begin{tabular}{|lll|}
\hline Participant's Characteristics & $\mathbf{n}(\%)$ \\
$\mathbf{N = 2 5 2}$ & Mean (SD) \\
\hline Time until first smartphone use in the morning (minutes) & \multicolumn{1}{c|}{$14.68(34.92)$} \\
\hline Number of extra devices owned besides smartphone & $1.38(0.68)$ \\
\hline Most personally relevant smartphone function & 126 \\
Entertainment & $(50.0)$ \\
Non-entertainment & 126 \\
\hline Abbreviations: SD standard deviation, RM Ringgit Malaysia & $(50.0)$ \\
\hline $\begin{array}{l}\text { *Others, } \mathrm{n}(\%) \text { : Bumiputera 3 (1.2), Kadazan 2 (0.8), Bajau 1 (0.4), Bidayuh } 1 \text { (0.4), Bugis } 1 \text { (0.4), } \\
\text { Dusun 1 (0.4), Punjabi 1 (0.4), Siamese 1 (0.4), Sino-Kadazan 1 (0.4) }\end{array}$ \\
\hline
\end{tabular}

As Table 1 also shows, the participants owned a smartphone at an average of 7 years, whereby they make or receive calls about 32 minutes per day and spend about 4 hours per day other than calls, which in detail, the participants equally use their smartphone for entertainment (50\%) and non-entertainment (50\%) purposes. The participants' smartphone usage was around SAS-M score of 101.43 (25.15). They have about one extra device besides their smartphone and usually would first use their smartphone within 15 minutes after wake-up in the morning.

Most medical students scored zero as not experiencing symptoms of headache (36.1\%), dizziness (44\%), neck pain $(32.1 \%)$, hearing problem (63.9\%), vision problem (39.3\%), sleep disturbance $(24.6 \%)$, palpitation $(68.3 \%)$, general exhaustion $(43.3 \%)$, shortness of breath $(81.3 \%)$ and temporary memory loss $(60.3 \%)$. Overall, the total score of severity for all reported symptoms experienced were a mean of 17.84 (15.58) as tabulated in Table 2.

(Please insert Table 2 here)

There is a significant association between the Malay race, employed and highly educated parents as well as academic performance related to the increase of students' smartphone usage as shown in Table 3. Similar factors were noticeably related to the increase of some smartphone patterns as tabulated in Table 4. 
Table 3

Smartphone usage across sample characteristics

\begin{tabular}{|c|c|c|c|}
\hline \multirow[t]{2}{*}{ Factor } & \multicolumn{3}{|c|}{ Smartphone usage (SAS-M score) } \\
\hline & Mean (SD) & $t / r$ & $\mathrm{p}$ value \\
\hline \multicolumn{4}{|l|}{ Socio-demography } \\
\hline Age (years) & - & $-0.015^{a}$ & 0.814 \\
\hline Gender & $100.9(20.86)$ & $.213^{\mathrm{b}}$ & 0.832 \\
\hline Male & $101.6(26.45)$ & & \\
\hline \multicolumn{4}{|l|}{ Female } \\
\hline Race & $115.43(16.56)$ & $14.75^{\mathrm{b}}$ & $<0.001^{*}$ \\
\hline Malay & $80.50(20.92)$ & & \\
\hline \multicolumn{4}{|l|}{ Non-Malay } \\
\hline Socio-economy & - & $-0.003^{a}$ & 0.960 \\
\hline \multicolumn{4}{|l|}{ Parents' income (RM) } \\
\hline Parents' occupation & $107.53(22.53)$ & $7.430^{\mathrm{b}}$ & $<0.001^{*}$ \\
\hline Father & $82.74(23.63)$ & & \\
\hline \multicolumn{4}{|l|}{ Employed } \\
\hline \multicolumn{4}{|l|}{ Unemployed } \\
\hline Mother & $119.82(16.29)$ & $20.601^{b}$ & $<0.001^{*}$ \\
\hline Employed & $79.87(14.15)$ & & \\
\hline \multicolumn{4}{|l|}{ Unemployed } \\
\hline Parents' education level & $106.48(29.04)$ & $4.81^{\mathrm{b}}$ & $<0.001^{*}$ \\
\hline Father & $93.36(13.93)$ & & \\
\hline \multicolumn{4}{|l|}{ High } \\
\hline Low & & & \\
\hline
\end{tabular}

${ }^{a} r=$ Pearson's correlation coefficient; ${ }^{b} t=$ Student's t-test value Abbreviations: SD standard deviation, RM Ringgit Malaysia

${ }^{*} p$ value $=$ statistically significant at $<0.05$ 


\begin{tabular}{|c|c|c|c|}
\hline \multirow[t]{2}{*}{ Factor } & \multicolumn{3}{|c|}{ Smartphone usage (SAS-M score) } \\
\hline & Mean (SD) & $t / r$ & $\mathrm{p}$ value \\
\hline Mother & $105.48(32.62)$ & $3.001^{\mathrm{b}}$ & $0.003^{\star}$ \\
\hline High & $96.68(9.46)$ & & \\
\hline \multicolumn{4}{|l|}{ Low } \\
\hline Scholarship status & $100.81(25.74)$ & $0.791^{\mathrm{b}}$ & 0.430 \\
\hline Yes & $103.98(22.61)$ & & \\
\hline \multicolumn{4}{|l|}{ No } \\
\hline Academic performance & - & $0.987^{a}$ & $<0.001^{*}$ \\
\hline \multicolumn{4}{|c|}{${ }^{a} r=$ Pearson's correlation coefficient; ${ }^{b} t=$ Student's $t$-test value } \\
\hline \multicolumn{4}{|c|}{ Abbreviations: SD standard deviation, RM Ringgit Malaysia } \\
\hline *p value $=$ statistically si & nificant at $<0.05$ & & \\
\hline
\end{tabular}

(Please insert Table 4 here)

Multivariable analysis found that only employed father and entertainment as most personally relevant smartphone function are the significant main predictors towards TSS after controlling other factors (Table 5). TSS increases 7.431 score (Adj. $\beta=7.431,95 \% \mathrm{Cl}$ : 3.069, 11.793) with employed father status and increase 4.211 score (Adj. $\beta=4.211,95 \% \mathrm{Cl}$ : $0.460,7.962$ ) with entertainment smartphone function more than non-entertainment. 
Table 5

Factors associated with Total Score of Severity among medical students

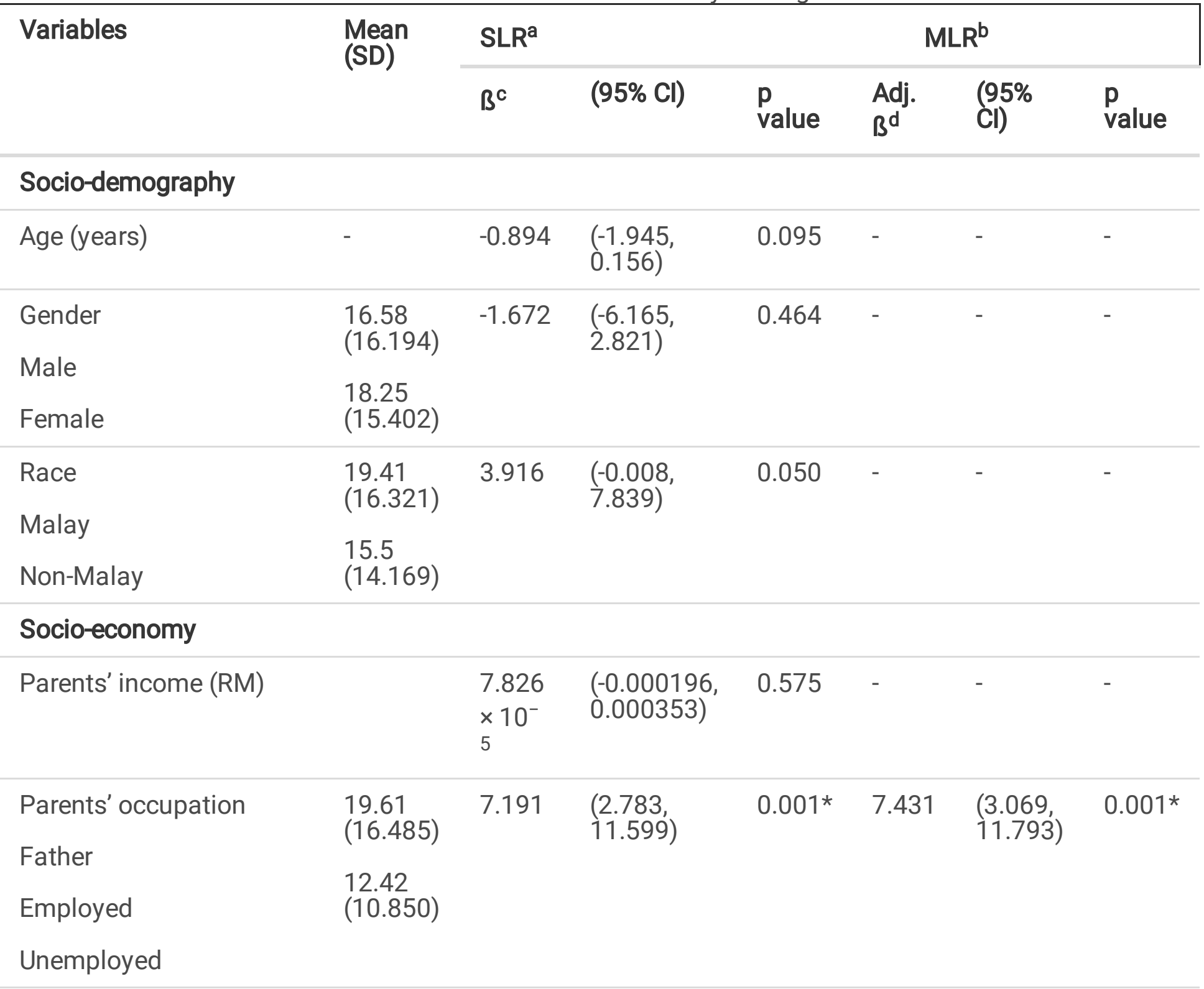

aSimple linear regression

${ }^{b}$ Multiple linear regression $\left(R^{2}=0.044\right)$

'Crude regression coefficient

${ }^{d}$ Adjusted regression coefficient

Notes: Multiple linear regression after controlling factors of socio-demography, socio-economic status and academic performance

${ }^{*} \mathrm{p}$ value $=$ statistically significant at $<0.05$ 


\begin{tabular}{|c|c|c|c|c|c|c|c|}
\hline \multirow[t]{2}{*}{ Variables } & \multirow{2}{*}{$\begin{array}{l}\text { Mean } \\
\text { (SD) }\end{array}$} & \multicolumn{2}{|l|}{$S L R^{a}$} & \multicolumn{4}{|c|}{$M L R^{b}$} \\
\hline & & $B^{c}$ & $(95 \% \mathrm{Cl})$ & $\begin{array}{l}p \\
\text { value }\end{array}$ & $\begin{array}{l}\text { Adj. } \\
B^{d}\end{array}$ & $\begin{array}{l}(95 \% \\
\mathrm{Cl})\end{array}$ & $\begin{array}{l}\mathrm{p} \\
\text { value }\end{array}$ \\
\hline \multirow{2}{*}{$\begin{array}{l}\text { Mother } \\
\text { Employed } \\
\text { Unemployed }\end{array}$} & $\begin{array}{l}19.19 \\
(16.572)\end{array}$ & 2.933 & $\begin{array}{l}(-0.937 \\
6.802)\end{array}$ & 0.137 & - & - & - \\
\hline & $\begin{array}{l}16.26 \\
(14.248)\end{array}$ & & & & & & \\
\hline \multirow{2}{*}{$\begin{array}{l}\text { Parents' education level } \\
\text { Father } \\
\text { High } \\
\text { Low }\end{array}$} & $\begin{array}{l}17.55 \\
(15.170)\end{array}$ & -0.744 & $\begin{array}{l}(-4.725 \\
3.236)\end{array}$ & 0.713 & - & - & - \\
\hline & $\begin{array}{l}18.30 \\
(16.294)\end{array}$ & & & & & & \\
\hline \multirow{2}{*}{$\begin{array}{l}\text { Mother } \\
\text { High } \\
\text { Low }\end{array}$} & $\begin{array}{l}19.01 \\
(15.509)\end{array}$ & 2.533 & $\begin{array}{l}(-1.341 \\
6.407)\end{array}$ & 0.199 & - & - & - \\
\hline & $\begin{array}{l}16.47 \\
(15.628)\end{array}$ & & & & & & \\
\hline \multirow{2}{*}{$\begin{array}{l}\text { Scholarship status } \\
\text { Yes } \\
\text { No }\end{array}$} & $\begin{array}{l}17.71 \\
(15.588)\end{array}$ & -0.653 & $\begin{array}{l}(-5.548 \\
4.241)\end{array}$ & 0.793 & - & - & - \\
\hline & $\begin{array}{l}18.37 \\
(15.720)\end{array}$ & & & & & & \\
\hline Academic performance & - & 4.492 & $\begin{array}{l}(-0.773 \\
9.757)\end{array}$ & 0.094 & - & - & - \\
\hline $\begin{array}{l}\text { Smartphone usage } \\
\text { characteristics }\end{array}$ & & 0.057 & $\begin{array}{l}(-0.020 \\
0.134)\end{array}$ & 0.144 & - & - & - \\
\hline SAS-M score & & & & & & & \\
\hline
\end{tabular}

aSimple linear regression

${ }^{b}$ Multiple linear regression $\left(R^{2}=0.044\right)$

${ }^{c}$ Crude regression coefficient

${ }^{d}$ Adjusted regression coefficient

Notes: Multiple linear regression after controlling factors of socio-demography, socio-economic status and academic performance

${ }^{*} \mathrm{p}$ value $=$ statistically significant at $<0.05$ 


\begin{tabular}{|c|c|c|c|c|c|c|c|}
\hline \multirow[t]{2}{*}{ Variables } & \multirow{2}{*}{$\begin{array}{l}\text { Mean } \\
(\mathrm{SD})\end{array}$} & \multicolumn{2}{|l|}{$S_{L R}{ }^{a}$} & \multicolumn{4}{|c|}{$M L R^{b}$} \\
\hline & & $B^{c}$ & $(95 \% \mathrm{Cl})$ & value & $\begin{array}{l}\text { Adj. } \\
\beta^{d}\end{array}$ & $\begin{array}{l}(95 \% \\
\mathrm{Cl})\end{array}$ & value \\
\hline $\begin{array}{l}\text { Smartphone pattern } \\
\text { characteristics }\end{array}$ & & 0.030 & $\begin{array}{l}(-0.009, \\
0.069)\end{array}$ & 0.128 & - & - & - \\
\hline \multicolumn{8}{|l|}{$\begin{array}{l}\text { Duration of smartphone } \\
\text { use making or receiving } \\
\text { calls on a typical day } \\
\text { (minutes) }\end{array}$} \\
\hline $\begin{array}{l}\text { Duration of smartphone } \\
\text { use other than calls on a } \\
\text { typical day (hours) }\end{array}$ & & -0.081 & $\begin{array}{l}(-0.533, \\
0.372)\end{array}$ & 0.726 & - & - & - \\
\hline $\begin{array}{l}\text { Duration of owning a } \\
\text { smartphone (years) }\end{array}$ & & 0.343 & $\begin{array}{l}(-0.356 \\
1.042)\end{array}$ & 0.334 & - & - & - \\
\hline $\begin{array}{l}\text { Time until first } \\
\text { smartphone use in the } \\
\text { morning (minutes) }\end{array}$ & & 0.024 & $\begin{array}{l}(-0.031 \\
0.080)\end{array}$ & 0.392 & - & - & - \\
\hline $\begin{array}{l}\text { Number of extra devices } \\
\text { owned besides } \\
\text { smartphone (devices) }\end{array}$ & & -0.452 & $\begin{array}{l}(-3.292, \\
2.389)\end{array}$ & 0.754 & - & - & - \\
\hline $\begin{array}{l}\text { Most personally relevant } \\
\text { smartphone function }\end{array}$ & $\begin{array}{l}19.92 \\
(16.959)\end{array}$ & 4.159 & $\begin{array}{l}(0.319 \\
7.999)\end{array}$ & $0.034 *$ & 4.211 & $\begin{array}{l}(0.460 \\
7.962)\end{array}$ & $0.028 *$ \\
\hline Entertainment & $\begin{array}{l}15.76 \\
(13.834)\end{array}$ & & & & & & \\
\hline Non entertainment & & & & & & & \\
\hline \multicolumn{8}{|l|}{ asimple linear regression } \\
\hline \multicolumn{8}{|c|}{${ }^{b}$ Multiple linear regression $\left(R^{2}=0.044\right)$} \\
\hline \multicolumn{8}{|c|}{${ }^{\circ}$ Crude regression coefficient } \\
\hline \multicolumn{8}{|c|}{${ }^{\mathrm{d}}$ Adjusted regression coefficient } \\
\hline \multicolumn{8}{|c|}{$\begin{array}{l}\text { Notes: Multiple linear regression after controlling factors of socio-demography, socio-economic status } \\
\text { and academic performance }\end{array}$} \\
\hline${ }^{\star} \mathrm{p}$ value $=$ statistically sig & ificant at $<0$ & & & & & & \\
\hline
\end{tabular}

\section{Discussion}

This study revealed the association of smartphone usage and pattern on self-reported symptoms among medical students of a Malaysian public university. Our participants' smartphone usage reflected on SASM score was 101.43 (25.15). Our result is about the same with other local studies with their findings of 
scores above 98 (15) and 102.52 (13). Other international studies are also in agreement with our findings as they are using the same score adapted in Spanish, Arabic and Turkish language, which higher score indicates increased risk of smartphone usage or addiction (23-25). In particular, medical students could be more vulnerable due to their heavy use of smartphones for study and work (26). Especially during the COVID-19 pandemic quarantine period, where this research was being conducted (16), high dependency on smartphone for learning purposes is expected. Those with high usage of smartphones reflects the local survey that $78 \%$ of Malaysians are smartphone users (27). There are currently no established diagnostic criteria of smartphone addiction according to Diagnostic and Statistical Manual of Mental Disorders (DSM-V) in the spectrum of addiction disorder, but the high usage aspects are similar to substance-related and addictive disorder (28).

The participants owned their smartphone at an average of 7 years in line with an Indian study revealing a majority of the students owned a duration of 1-8 years, as smartphone seems to be a necessity nowadays (29). Our findings that participants make or receive calls about 32 minutes per day and spending about 4 hours per day for other than calls are somewhat consistent with South Korean students where most used 2-4 hours of smartphone daily (30). In contrast, a Pakistani study (31) revealed, 11 to 14 hours daily of smartphone use among medical doctors and this is probably because of age differences, as this study focused on young adults (mean age of 23). They spend more time on instant gratification applications whereby Malaysians seem to follow local trends by using apps like, WhatsApp, Instagram and Facebook (21). Unlike any other, a smartphone is the medium of choice for interpersonal mediated communication among young adults. This generation has a culture of smartphone being their companion, where they play, chat, shop and spend their leisure time in a profound and fundamental way different from their parents. Our participants equally use their smartphone for entertainment (50\%) and non-entertainment (50\%) purposes which does not support a study from India where most used their smartphones for purposes of social interaction (32). We also found the students would usually first use their smartphone within 15 minutes after wake-up in the morning differs with the Swiss youths (33) that majority spent within 5 minutes. The number of device owned has somewhat increase to an extra one device as compared to a local study (34), which may be the reason to devices' affordability and availability in the market. It is recognized that it is difficult to draw definitive conclusions regarding the usage of smartphones, because cultures, values and beliefs vary across the world and play a role in the understanding and use of technology. The scenario supports The Uses and Gratification Theory (UGT), about why people turn to technology to meet their social and psychological needs at the same time, implies that they are deeply involved in their decision to use the technology and how to use it to meet their needs $(35,36)$.

Most medical students scored zero as not experiencing symptoms of headache (36.1\%) and vision problem (39.3\%). However, this is incomparable with 53.5\% of Iranian students experienced headache (22) and $82.1 \%$ Iraqi students experienced vision problems (19). Even though findings did not support our hypothesis that headache will be the most common self-reported symptoms, it is a concerning issue, in view of the proportion of students still having symptoms of different severity which are sleep disturbance (75.4\%), followed by neck pain (67.9\%), headache (63.9\%), vision problem $(60.7 \%)$ and general 
exhaustion (56.7\%). The symptoms distributions are somewhat varies from the Iraqi students (19) in detail, sleep disturbance $(58.5 \%)$, neck pain $(73.8 \%)$, headache $(64.6 \%)$, vision problem $(82.1 \%)$ and general exhaustion (69.9\%). In 2011, the National Radiological Protection Board raised an issue that a large proportion of microwave frequency energy will eventually penetrates the user's body parts and head (37), by up to 2 inches of the human brain (38). Current guidelines set out by the International Commission on Non-Ionizing Radiation Protection (39) has raised issues in adults that, the radiation induced by smartphones has negatively affect cognitive functions, cell communication and fertility (40, 41). On the other hand, there are opposite results that indicate no such risks caused by smartphone exposure $(42,43)$. The non-ionising radiation emitted from a smartphone is however not strong enough to break atomic bonds and cause tissue damage (44). This could explain on our outcome of the low mean TSS score, whereby, the current evolution of smartphone inventions is more user-friendly with safety features of low emitting radiations and ergonomically proper as compared to the early generations of smartphones or mobile phones which reported side effects (45). The relevance of these consequences to human health is unclear as classified by the International Agency for Research on Cancer as group 2B (limited evidence in humans but less than sufficient evidence in experimental animals) (46). These effects have not been verified independently given the frequent lack of reproducibility of biological RF effects. With decades of cancer and neurodegenerative disease latencies, it will take some time to see the possible adverse effects (45), by that time, for many, it will be too late.

Further bivariate analysis revealed significant features associated with smartphone usage are, being Malay, having employed and highly educated parents and academic performance. Malay ethnicity was found significant as it is the majority ethnic in Malaysia (47). The findings of employed parents is inconsistent with a study from Korea, whereby, parents of the children showing the highest addictive tendency to smartphone use are predominantly lack stable jobs, and have less than a high school degree (48).The reason could be that the sample population are amongst children as compared to university students. On the other hand, increase in smartphone usage outcome differs with our finding, whereby a study from Iran found academic achievement reduces as students would have more mental occupation which leads to attention deficit and loss of focus in classroom. (49). While highly educated parents were found significantly associated with smartphone usage and certain smartphone patterns (making or receiving calls, purpose other than calls and extra devices owned). This is fairly similar to a local study that found positive correlation with smartphone usage which reflects high socioeconomic status represents the affordability to support the students' smartphones monthly usage $(12,35)$.

There are two main predictors that determine the severity of symptoms, the medical students perceived they experienced. Firstly, father's occupation or employed status contributes to the medical students' TSS. Our finding is somewhat contrary due to age difference, focussing on South Korean children's high usage of smartphone reflected from parents not having stable work with less than a high school diploma (48). Those parents are most likely unaware of their duty to monitor the use of their children's smartphones. The ability to adequately care for their children also lacks in identifying the symptoms that their children can encounter from smartphone exposure. It has also been verified that trends in the use of children's smartphones draws forth to psychological behaviours $(50,51)$, based on smartphone fascination, 
opportunities for peer interaction and physical activity may decrease, hence, lead to adverse physical symptoms in the long run. These phenomena signify parenting implications on children's educational environment as their development may be influenced negatively by smartphone exposure which can be translated into symptoms severity.

The other contributor to the increment of TSS score is entertainment function of smartphone use, congruent with an Iranian study (22). The medical students detailed out their most personally relevant smartphone function are entertainment such as, listen to music, play games, watch videos, read comics, and maintain social interaction on Social Networking Service especially during the time of COVID-19 quarantine period. This is backed by Zuckerman's sensation-seeking theory of experience finding exposure and the resistance to boredom (52). However, to an extent, prolonged smartphone exposure leads to different forms of symptom severity experienced due to: (a) poor ergonomics (headaches, neck, shoulder and jaw pain) from anterior head syndrome (7) and (b) EMF or blue light exposure (sleep disturbances, blurry vision, concentration problems, dry and irritated eyes) $(53,54)$. More younger generations are affected by the popularity of education and entertainment technologies as they are in the midst of development that causes abnormal stress to the spine and digital eye strain can negatively influence their overall development and well-being (53).

We made all necessary steps to ensure optimum results, but the generalisability of these results is subjected to certain limitations. First, it was unavoidably conducted in different settings. The study was initially conducted before the order of nationwide quarantine due to COVID-19 global pandemic (16), and half the responses were completed during the period of quarantine, which more screening time than usual would be expected from the respondents. While they were residing at their respective locations, every student is depending heavily on the e-learning system implemented by the university (55). In regards to completing the questionnaire, we cannot avoid the probability of reporting bias from self-reported data. Nevertheless, the present study extends our knowledge of smartphone exposure towards self-reported symptoms' severity as perceived by the medical students in addition to the available evidence of smartphones affecting psychological health $(13,15,24,50,51)$.

\section{Conclusions}

In conclusion, we identified that self-reported symptoms among medical students are affected by the occupation of the fathers and smartphone entertainment purposes during the COVID-19 outbreak. Therefore, with currently no policy that regulates proper ways to utilise smartphones, effort and parental control by parents initiated from early childhood education is required. Supportive systems providing counselling or avoidance therapy on many ways of seeking entertainment should be established when children note a clear propensity to choose smartphones. Above all, active participation by parents is crucial for these public efforts to be effective. Public programs to raise awareness of effective ways of using smartphones from early childhood, and various educational programs are essential to prevent smartphone dependency. It would be interesting to assess parental smartphone usage and pattern habits as mediating factor. Additional research is needed to identify a causal relationship between smartphones 
usage and pattern and its association on other health related outcomes to gain insight in its long-term effects as it may take some time to become evident. There is no conclusive evidence of adverse health effects but neither has the research shown that smartphones are safe.

\section{List Of Abbreviations}

Cl: confidence interval

COVID-19: 2019 novel coronavirus

EMF: electromagnetic fields

MLR: Multiple Linear Regression

SAS-M: Smartphone Addiction Score - Malay

SD: standard deviation

SES: socio-economic status

TSS: Total Score of Severity

UGT: The Uses and Gratification Theory

UKM: Universiti Kebangsaan Malaysia

Wi-Fi: wireless fidelity

\section{Declarations}

\section{Ethics approval and consent to participate}

Ethics approval for this study was obtained from the Ethics Committee of Universiti Kebangsaan Malaysia (FF-2020-105). All the participants consented before taking part in this study.

\section{Consent for publication}

Not applicable.

\section{Availability of data and materials}

The datasets used and/or analysed during the current study are available from the corresponding author on reasonable request.

Competing interests 
The authors declare that they have no competing interests.

\section{Funding}

The authors received no financial support for the research, authorship and/or publication of this article.

\section{Authors' contributions}

MNA and MKPSN designed the study and wrote the proposal. MKPSN undertook the data collection and statistical analysis and wrote the manuscript draft. MNA guided and supervised the study throughout, data analysis and interpretation as well as critically revised the manuscript drafts. Both authors contributed to and approved the final manuscript for submission and publication.

\section{Acknowledgements}

We thank the participants for sharing their inputs and experiences. We would like to thank the Dean of Faculty of Medicine, Universiti Kebangsaan Malaysia for the permission to publish this article.

\section{Authors' information}

${ }^{1}$ Department of Community Health, Faculty of Medicine, Universiti Kebangsaan Malaysia, Jalan Yaacob Latif, Bandar Tun Razak, 56000 Kuala Lumpur, Malaysia

\section{References}

1. Byun Y-H, Ha M, Kwon HJ, Choi KH, Burm E, Choi Y, et al. Epidemiological Characteristics of Mobile Phone Ownership and Use in Korean Children and Adolescents. Environmental Health Toxicology. 2013;28:1-8.

2. Sanz AB, Figuero CR, Alonso RP, Río ZGD, Herrero MH, González NC. Mass media consumption in adolescence. An Pediatr. 2005;63(6):516-25.

3. Zheng F, Gao P, He M, Li M, Tan J, Chen D, et al. Association between mobile phone use and selfreported well-being in children: a questionnaire-based cross-sectional study in Chongqing, China. BMJ Open. 2015;5(5):1-7.

4. Mortazavi SMJ, Atefi M, Kholgh F. The Pattern of Mobile Phone Use and Preva- lence of SelfReported Symptoms in Elementary and Junior High School Students in Shiraz, Iran. Iranian Journal of Medical Sciences. 2011;36(2):96-103.

5. Soderqvist F, Carlberg M, Hardell L. Use of wireless telephones and self-reported health symptoms: a population-based study among Swedish adolescents aged 15-19 years. Environ Health. 2008;7(18):1-10.

6. Zou Y, Xia N, Zou Y, Chen Z, Wen Y. Smartphone addiction may be associated with adolescent hypertension: a cross-sectional study among junior school students in China. BMC Pediatrics. 2019;19(1):310. 
7. C7-T1 Facet Joint Osteoarthritis Cause By Prolonged Use of Smart Phone Ali OTO. C6-C7 and C7-T1 Facet Joint Osteoarthritis Cause By Prolonged Use of Smart Phone. MultiKnowledge Electronic Comprehensive Journal For Education \& Science Publications (MECSJ). 2019(26):1-9.

8. Singh MKK, Samah NA. Impact of Smartphone: A Review on Positive and Negative Effects on Students. Asian Social Science. 2018;14(11).

9. Frumkin H, Jacobson A, Gansler T, J.Thun M. Cellular phones and risk of brain tumors. Environmental Carcinogens. 2001;51(2):137-41.

10. Karinen A, Heinavaara S, Nylund R, Leszczynski D. Mobile phone radiation might alter protein expression in human skin. BMC Genom. 2008;9(77):1-5.

11. Kumar LR, Chii KD, Way LC, Jetly Y, Rajendaran V. Awareness of mobile phone hazards among university students in a Malaysian medical school. Health. 2011;3(7):406-15.

12. Zulkefly NS, Rozumah Baharudin. Mobile Phone use Amongst Students in a University in Malaysia: Its Correlates and Relationship to Psychological Health. Eur J Sci Res. 2009;37(2):206-18.

13. Norbaidurah Ithnain SE, Ghazali, Jaafar N. Relationship between Smartphone Addiction with Anxiety and Depression among Undergraduate Students in Malaysia. International Journal of Health Sciences Research. 2018;8(1):163-71.

14. Mohamad Ashari Z, Ngadiman AA, Zainudin NF, Jumaat NF. The Relationship between Knowledge and Attitude towards Technology Gadget Usage with Students' Socio-Emotions Development. International Journal of Interactive Mobile Technologies (iJIM). 2018;12(7).

15. Nikmat AW, Nurul Azreen Hashim, Muhammad Farid Saidi, Nur Suhailah Mohd Zaki, Nur Nabihah Hasan Shukri, Abdulla NB. The Use And Addiction To Smart Phones Among Medical Students And Staffs In A Public University In Malaysia. ASEAN Journal of Psychiatry. 2018;19(1):1-7.

16. Eizairi Shamsudin. 14-day Movement Control Order begins nationwide on Wednesday. New Straits Times. 202016 March 2020.

17. Tang A. Malaysia announces movement control order after spike in Covid-19 cases (updated). The Star. 2020;Sect. Nation.

18. Kish L. Survey Sampling. New York: John Wiley and Sons, Inc; 1965.

19. Abed SN, Abd RK, Salim ID, Abdul N, Razzaq Jamal. Health problems of Mobile Phone Addiction for sample of students and their health awareness at Institute Technical of Kut. Journal of Pharmaceutical Sciences Research. 2018;10(2):412-5.

20. Ching SM, Yee A, Ramachandran V, Sazlyna Mohd Sazlly Lim, Wan Aliaa Wan Sulaiman, Foo YL, et al. Validation of a Malay Version of the Smartphone Addiction Scale among Medical Students in Malaysia. PLOS One. 2015;10(10):1-11.

21. Kwon M, Lee JY, Won WY, Park JW, Min JA, Hahn C, et al. Development and validation of a smartphone addiction scale (SAS). PLoS One. 2013;8(2):1-7. 
22. Mortazavi SMohammadJ, Atefi M, Kholghi F. The Pattern of Mobile Phone Use and Prevalence of Self-Reported Symptoms in Elementary and Junior High School Students in Shiraz, Iran. Iranian Journal of Medical Sciences. 2011;36(2):96-103.

23. Fernandez OL. Short version of the Smartphone Addiction Scale adapted to Spanish and French: Towards a cross-cultural research in problematic mobile phone use. Addict Behav. 2015;64:275-80.

24. Alhassan AA, Alqadhib EM, Taha NW, Alahmari RA, Salam M, Almutairi AF. The relationship between addiction to smartphone usage and depression among adults: a cross sectional study. BMC Psychiatry. 2018;18(1):148.

25. Demirci K, Akgonul M, Akpinar A. Relationship of smartphone use severity with sleep quality, depression, and anxiety in university students. Journal of Behavioral Addictions. 2015;4(2):85-92.

26. Jamal A, Sedie R, Haleem KA, Hafiz N. Patterns of use of 'smart phones' among female medical students and self-reported effects. Journal of Taibah University Medical Sciences. 2012;7(1):45-9.

27. Malaysian Communications and Multimedia Commission. Hand Phone Users Survey 2018. 2018:155.

28. Lin YH, Chang LR, Lee YH, Tseng HW, Kuo TBJ, Chen SH. Development and Validation of the Smartphone Addiction Inventory (Spain). PLoS One. 2014;9(6):1-5.

29. Maurya P, Penuli Y, Kunwar A, Lalia H, Negi V, Williams A, et al. Impact of Mobile Phone Usage on Psychosocial Wellbeing of Student Nurses. Journal of Nursing Health Science. 2014;3(6):39-42.

30. Lee KE, Si Heon Kim, Ha TY, Yoo YM, Han JJ, Jung JH, et al. Dependency on Smartphone Use and Its Association with Anxiety in Korea. Public Health Rep. 2016;131:411-131.

31. Larik RSA, Mallah GA, Talpur MMA, Saeed A, Larik FA, Suhag AK, et al. Adverse Effects of Cell Phone Radiation on Human Health. International Journal of Scientific Engineering Research. 2016;7(10):480-6.

32. Ganganahalli P, Tondare MB, Durgawale PM. Use of Electronic Gadgets among Medical Students in Western Maharashtra, India. International Journal of Health Sciences Research. 2014;4(9):26-30.

33. Haug S, Castro RP, Kwon M, Filler A, Kowatsch T, Schaub MP. Smartphone use and smartphone addiction among young people in Switzerland. J Behav Addict. 2015;4(4):299-307.

34. Kumar LR, Chii KD, Way LC, Jetly Y, Rajendaran V. Awareness of mobile phone hazards among university students in a Malaysian medical school. Health. 2011;03(07):406-15.

35. Balakrishnan V, Raj RG. Exploring the relationship between urbanized Malaysian youth and their mobile phones: A quantitative approach. Telematics Inform. 2012;29(3):263-72.

36. Leung L. Unwillingness-to-communicate and college students' motives in SMS mobile messaging. Telematics Inform. 2007;24(2):115-29.

37. National Radiological Protection Board. Mobile Telephony and Health: Exposures from Mobile Phones. 2011.

38. Bhargavi K, Balachandrudu K, Nageswar P. Mobile Phone Radiation Effects on Human Health. International Journal of Computational Engineering Research. 2013;3(4):196-203. 
39. International Commission on Non-lonizing Radiation Protection. Guidelines for Limiting Exposure to Time-Varying Electric and Magnetic Fields (1 Hz to 100 kHz). Health Phys. 2010;99(6):818-36.

40. Bioinitiative. A Rationale for a Biologically Based Public Exposure Standard for Electromagnetic Fields. 2007.

41. ECOLOG. Mobile Telecommunications and Health. Summary of the ECOLOG study for T- Mobile. 2000.

42. Mobile Telecommunications and Health Research Programme. A Report of UK Health Protection Agency. 2007.

43. Valberg PA, Deventer TEV, Repacholi MH. Workgroup Report: Base Stations and Wireless NetworksRadiofrequency (RF) Exposures and Health Consequences. Environmental Health Perspectives. 2007;115(3).

44. Md Ahsan Iftekhar Uddin, Jannatul Ferdous. Radiation Exposure of Cell Phones \& Its Impact on Human Health - a Case Study in South Asia (Bangladesh) and Some Recommendations. Journal of Theoretical and Applied Information Technology. 2010:15-21.

45. Cherry N. Cell phone radiation poses a serious biological and health risk. Canterbury, Environmental Management and Design Division;: Lincoln University; 2001.

46. Kim KH, Kabir E, Jahan SA. The use of cell phone and insight into its potential human health impacts. Environmental Monitoring Assessment. 2016;188(4):221.

47. The Malaysian Administrative Modernisation and Management Planning Unit. Demography of Population Putrajaya 2016 [Available from: https://www.malaysia.gov.my/portal/content/30114. Accessed 13 July 2020.

48. Cho KS, Lee JM. Influence of smartphone addiction proneness of young children on problematic behaviors and emotional intelligence: Mediating self-assessment effects of parents using smartphones. Comput Hum Behav. 2017;66:303-11.

49. Saadatmand MAS, Moghadam Z, Fathi G, Afshar R. The Relationship between Mobile Cellphone Dependency, Mental Health and Academic Achievement. American Journal of Educational Research. 2016;4(5):408-11.

50. Xie H, Tao S, Zhang Y, Tao F, Wu X. Impact of problematic mobile phone use and insufficient physical activity on depression symptoms: a college-based follow-up study. BMC Public Health. 2019;19(1):1640.

51. Tan QYJ, Hartanto A, Toh WX, Yan H. Commentary. Influence of smartphone addiction proneness of young children on problematic behaviors and emotional intelligence: Mediating self-assessment effects of parents using smartphones. Front Psychol. 2019;10(115):1-3.

52. Zuckerman M. Sensation seeking: beyond the optimal level of arousal. New York: Hillsdale, N.J., Erlbaum Associates;; 1979.

53. Baeuchamp N. 4 Sneaky Ways Technology is affecting your family's health and may affect your child's new school year. Exceptional Parent (EP) Magazine. 2019. 
54. Belyaev I, Dean A, Eger H, Hubmann G, Jandrisovits R, Kern M, et al. EUROPAEM EMF Guideline 2016 for the prevention, diagnosis and treatment of EMF-related health problems and illnesses. Reviews on Environmental Health. 2016:1-35.

55. Pusat Pengajaran \& Pembangunan Kurikulum Universiti Kebangsaan Malaysia. UKM Folio Learning Management Sytem 2020 [Available from: https://ukmfolio.ukm.my/. Accessed 17 May 2020.

\section{Tables 2 And 4}

\section{ADDITIONAL FILES}

Additional file 1: Table 2 - Self-reported symptoms among medical students

Additional file 2: Table 4 - Smartphone pattern across sample characteristics

\section{Supplementary Files}

This is a list of supplementary files associated with this preprint. Click to download.

- AdditionalFile2Table4.xml

- AdditionalFile1Table2.xml 